\title{
Biological Control of the Weedy Plant (Rumex crispus) at the Seedling Growth Stage by the Green Dock Beetle (Gastrophysa viridula)
}

\author{
Khalid S. Alshallash \\ College of Sciences, Shaqra University, Shaqra, Saudi Arabia \\ kalshallash@su.edu.sa
}

\begin{abstract}
In four glasshouse experiments, the effectiveness of the adult green dock beetle Gastrophysa viridula (Coleoptera: Chrysomelidae), at the effective number of applied individuals, for use as a biological control agent of curled dock, Rumex crispus (Polygonaceae) were studied. The feeding of the beetle was investigated at four different numbers of beetle $(0,1,2,3)$ and at four seedling growth stages of the plant, defined by the average of leaf area per plant $(1-1.22,2$ $4.45,3-11.56$, and $4-71.52 \mathrm{~cm} 2 /$ plant). Grazing by one, two or three dock beetles did not result in a significant reduction in dock dry weight or shoot numbers at the youngest growth stage. However, both at later seedling growth stages were significantly affected $(\mathrm{P} \leq 0.0001)$, at any beetles number. The increase of beetle numbers caused nonsignificant increased effect, in some trials, confirming the impact of a single beetle. Three months after beetle grazing, dock seedlings of first, second and third growth stages were not able to regrow, however, some plants at the 4th growth stage, re-emerged. This suggested that the highest effect of beetle's feeding occurs on the early seedling stages. Statistical analysis showed a positive correlation (0.77) between dry weight and shoot number at all the four seedling growth stages, thus confirming the impact of the beetle on both the dry weight and shoot numbers. Combining beetle grazing with other control methods at older dock seedling stages could, therefore, provide better suppression.
\end{abstract}

Keywords. Curled dock, Rumex crispus, Seedlings, Green dock beetle, Gastrophysa viridula, Biological control, Regeneration.

\section{Introduction}

Weedy plants are widely dispersed and persist in arable, rangelands, forests and aquatic ecosystems (Sher and Alyemeny, 2011). In cultivated environments, they have been widely recognised as constraints on agricultural production systems, where they compete with cultivated plants for the available resources needed for growth resulting in negative effects on crop yield and productivity (Strokey, 2006). Resources for which competition occurs include water, nutrients, mineral salts, light, space (Hill, 1977; Zhao et al., 2006; Dunbabin, 2007) and their requirements have been described as practically the same as the crops with which they cohabit. Weeds population usually persist in both pasture and arable croplands, despite repeated applications of a variety of control methods (e.g., herbicides).Weeds have been shown to be allelopathic (Khanh et al., 2005; Belz et al., 2007; Javaid et al., 2007), depressing growth in desirable plants with toxic residues (Singh et al., 2005). Weeds are also reported to act as banker plants for diverse plant pests (Oudejan, 1994).

Rumex crispus L. (Polygonaceae), curled dock, is widely reported to be one of the most 
problematic weed species worldwide. Zaller (2004), reviewed 700 research papers, concentrating on dock ecology and control. He concluded that there are still many aspects of its ecology and, particularly non-chemical, control have yet to be addressed. Rumex species are of great importance from the agricultural point of view since they are abundant and exhibit the typical weedy characteristics of competing with sown plants and pasture species for space and resources (Salt and Whittaker, 1998). For example, in Germany, seven of 10 pastoral farms have been heavily contaminated by Rumex species (Bach, 1992; Hofmann, 1992) and in Japan, $60 \%$ of grasslands have been reported to be invested by them (Hongo, 1986). In Europe, $80 \%$ of the herbicides have been estimated to be used in grassland farming are for control of Rumex (Gallery, 1989).

The traits which make $R$. crispus and other perennial Rumex species so difficult to control include their ability to germinate from seed, combined with massive seed production, and multiple repeat flowerings in any given years. Seed can remain viable in the soil for many years and germinate under different environmental conditions, with quick seedling establishment. The persistent taproot system readily regrows after cutting or from fragments left after damage (Cavers and Harper, 1964; Gwynne and Murray, 1985; Pino et al., 1995; Pye, 2008). Dock seedlings are very widespread and abundant plants in such open habitats (Cavers and Harper, 1964). There are widely reported difficulties in chemical control of these species, which, along with an increasing interest in organic farming practice, those encouraged the use of natural enemies to control them (Martinkova and Honek, 2004). It was reported that releasing of specific biocontrol agents against certain species of weeds can reduce the weeds' adverse effects on crop plants (Harley and Forno, 1992; Julein and White, 1997). The most thoroughly studied organisms with regard to Rumex biocontrol are the Coleoptera, mainly including the green dock beetle Gastrophysa viridula (Coleoptera : Chrysomelidae). This beetle is a widespread native of Europe, living in predominantly humid habitats. After eclosion, the larva has three instars before pupation. Its life-cycle takes about 24 days. In the laboratory, five generations per year can be reared, whereas only 2-4 generally occur in the field, depending on the habitat and prevalent environmental conditions (Dagmar et al., 2011). Because of its potential value in the biological control of Rumex sp., its biology was studied by Dagmar et al., (2011). However, the use of $G$. viridula for the control of Rumex species as weeds, it needs to be combined with other control measures to give total control (Martinkova and Honek, 2004). $G$. viridula beetles have been reported to reduce Rumex seed production, affecting its regeneration and hence reducing its adverse impacts, however, even when severely attacked, Rumex plants were rarely killed (Zaller, 2004). There have been several studies investigating the effects of the beetle, for instance, on Rumex growth, however, no attempts have been made to quantify this effect, particularly during early growth stages of Rumex. The present study was carried out to quantify the effects of green dock beetle on Rumex crispus at its early growth stages.

\section{Materials and Methods}

\subsection{Growing of Rumex Crispus Seedlings for Experimental Trials}

Commercial seed samples of Rumex crispus (supplied by Hebiseeds, Surrey, UK) were sown in 2503.5 inch pots at the beginning of September 2014, in a glasshouse at the School of Biological Sciences, University of Reading, UK. Pots were filled with mixed soil of loam, sand and organic 
matter at a ratio of 50:25:25\%. One seed per pot was buried just beneath the soil surface. Plants were irrigated regularly and NPK $(17 \%, 11 \%$, and $10 \%)$ fertilizer, at the rate equivalent to $25 \mathrm{~kg} \mathrm{ha}^{-1}$, was added to each pot, two weeks after sowing, to enhance shoot emergence and growth. A number of 112 pots were randomly selected and marked for the definition of plant stage by leaf area measurements. The remaining 138 pots were left for the introduction of beetles, as described below.

\subsection{Definition of Plant Developmental Stages}

In order to define the leaf stage, the leaf area per plant of 28 seedlings at each of the 4 growth stages were estimated. Leaf area of other 28 seedlings of the same growth stage, was measured also using an image analyser and software (Win DIAS with DIAS 3.2, Delta-T Devices, Cambridge, UK). A linear regression was conducted to identify the following equation for relating estimated (by measurement) to actual (from Win DIAS) areas.

$$
\mathrm{Y}=\mathrm{B} \text { constant }+\mathrm{B} \operatorname{var} \mathrm{X}
$$

Where $\mathrm{Y}=$ WinDIAS (actual) area, $\mathrm{B}$ is a constant (intercept) and $\mathrm{X}$ is the estimated area.

The developmental growth stage of plants used in experimental trials were measured prior to each experiment and before beetles' release or use as control, and the leaf area calculated based on the equation above. The developmental growth stages were defined by the determination of the mean of leaf area per plant. Therefore, four selected growth points, were determined by leaf area, representing the seedling developmental stages: $1-1.22 \mathrm{~cm}^{2} /$ plant, $2-4.45 \mathrm{~cm}^{2} /$ plant, 3 $-11.56 \mathrm{~cm}^{2} /$ plant, and $4-71.52 \mathrm{~cm}^{2} /$ plant .

\subsection{Rearing of Gastrophysa viridula}

Gastrophysa viridula eggs were collected from Rumex spp leaves in the field in wild areas in the north of Wales in August 2014 and reared in the laboratory on moistened filter paper in Petri dishes. The temperature in the laboratory ranged from 22 to $10^{\circ} \mathrm{C}$ around the 24 hours during the time of beetle rearing. Light was available during the day time. Relative humidity was maintained around $65 \%$. After hatching, larvae were moved to air and light admitting but secure plastic containers. Larvae were fed daily with freshly collected Rumex obtusifolius or Rumex crispus leaves. When adults emerged from the pupal stage, they were moved to new containers and also fed daily. The cycle was repeated over three months to maintain sufficient stock of the bioagent.

\subsection{Releasing G. viridula on R. crispus seedlings}

Experiments were conducted in a greenhouse at $14-22^{\circ} \mathrm{C}$ and relative humidity ranging between $65-75 \%$. Plants in 7 replicates at each growth developmental stage were randomly infested with either 0 (control), 1, 2 or 3 adult beetles and immediately sealed in a plastic bag. The infestation procedure was repeated on new plants at all 4 target growth points. Sealed, infested plants were placed onto constantly moistened sponge matting, in open plastic trays. Beetles were allowed to graze for 72 hours then returned to their containers. Seedlings were harvested and dry weight and shoot numbers per plant (i.e. per pot) were measured and counted. Pots were removed from the trays and watered regularly for three months to monitor long-term reaction after beetle grazing.

\subsection{Statistical Analysis}

Data from the four experimental stages were combined as the same procedures were followed. One way ANOVA was undertaken using (GENSTAT Version 18, VSN International, and Hemel Hempstead, UK). Mean comparisons were performed by a least 
significant difference (LSD) multiple comparison test.

\section{Results}

\subsection{Growth of the Four Seedling Stages of Rumex crispus}

Table 1 shows the average dry weights $\left(\mathrm{gm}^{*}\right.$ plant $^{-1}$ ) and shoots number/plant for the four growth stages of seedling before each experiment in the absence of beetle infestation (control treatment).

The dry weight (gm/plant) of growth stage 1 was significantly lower $(P \leq 0.02)$ than the subsequent growth stages. There was nonsignificant difference in dry weight between stages 2 and 3. However, at stage 4, dry weight was significantly $(\mathrm{P} \leq 0.001)$ higher than either of the previous growth stages. Shoot numbers/plant at the first growth stage was significantly less than the third and fourth growth stages. However, there was nonsignificant difference in number of shoots/plant between the second, third and fourth stages, suggesting all shoots are produced at the time of emergence or shortly after.

\subsection{Effect of Beetle Grazing on the Dry Weight of R. crispus}

Beetle grazing reduced the mean dry weight of $R$. crispus at all 4 stages of growth (Fig. 1). ANOVA showed significantly $(\mathrm{P} \leq$ 0.001) lower average dry weight of plants when seedlings were infested with one beetle per plant, but the effect did not increased significantly with increase in numbers of beetles to 2 or 3 per plant.

The percentage of reduction in average of $R$. crispus dry weight (gm* plant $^{-1)}$ for the 4 growth stages as a result of grazing by 1 or 2 beetles was $44 \%$, compared to the control $(0 \%)$. Infestation of 3 beetles resulted in the reduction of dry weight $\left(\mathrm{gm}^{*}\right.$ plant $\left.{ }^{-1}\right)$ by $73 \%$ (Fig. 2). However, this result was nonsignificant. A single beetle was, therefore, capable of inflicting equivalent damage per plant similar to 2 or 3 beetles.

\subsection{Effect of Beetle Grazing on Shoot Numbers of $R$. crispus}

The average number of shoots per plant at the combined growth stages was significantly reduced than control at all levels of beetle grazing ( $\mathrm{P} \leq 0.001$; Fig. 3$)$. The Increase in the number to 2 or 3 beetles*plant1 caused similar and slightly lower reductions in shoots number, being nonsignificant than that counted by releasing 1 beetle. Infestation of 1 beetle reduced the average number of shoots per plant by $49 \%$ (Fig.4). However, with 2 beetles, the reduction was less $(41 \%)$ and with 3 beetles it was $58 \%$. The differences were nonsignificant. A single beetle was, therefore, capable of inflicting equivalent damage per plant similar to 2 or 3 beetles.

\subsection{Effect of Increasing Number of beetles on the Dry Weight of R. crispus at Different Growth Stages}

At growth stage 1 (leaf area: $1.22 \mathrm{~cm}^{2}$ ), beetle grazing did not significantly reduce the dry weight (gm* plant $\left.{ }^{-1}\right)$ (Fig. 5). However, at growth stages 2-4 (leaf areas: 4.45, 11.56 and $71.52 \mathrm{~cm}^{2}$, respectively), dry weight was reduced significantly by 1 beetle $(\mathrm{P} \leq 0.002)$. This effect became more prominent as beetle numbers increased, but not significant.

\subsection{Effect of Increasing Number of Beetles on the Number of Shoots of R. crispus at the Four Growth Stages}

At growth stage 1, (leaf area: $1.22 \mathrm{~cm}^{2}$ ) shoot counts per plant were reduced, but the effect was, statistically, nonsignificant, and was equivalent to those occurred by 2 or 3 abundancies of beetles (Fig. 6). However, at stages 2-4 (leaf areas: 4.45, 11.56 and 71.52 $\mathrm{cm}^{2}$, respectively), the number of shoots was significantly reduced $(\mathrm{P} \leq 0.05)$, with, 
however, lower effects by 2 beetles at plant stages 2 and 3 than by 1 or 3 beetles. At plant stage 4 , there a trend appeared towards greater reduction in shoot numbers as beetle numbers increased, however, the differences were nonsignificant. Hence, at least at stages 1-3, one grazing beetle was found to be effective by reducing the shoot count by an equivalent amount to 2 or 3 beetles.

\subsection{Regeneration of $R$. crispus Seedlings After Beetle Grazing}

Three months after beetle grazing, the $R$. crispus seedlings grazed by beetles at growth stages 1-3 did not regrow, and their death was confirmed (Table 2). The plants at stage 4 (leaf area: $71.52 \mathrm{~cm}^{2}$ ), were able to regrow after any tested level of beetle grazing.

Table 1. Table 1. Definition of the developmental stages of Rumex crispus by dry weight (gm*plant-1) and shoot count (shoots/plant) at the four growth stages of control plants. * Least significant difference between the means. (Figures with same letter not significant).

\begin{tabular}{|c|c|c|}
\hline $\begin{array}{c}\text { Growth stage } \\
\text { (average leaf area }\left(\mathrm{cm}^{2}\right) / \text { plant) }\end{array}$ & $\begin{array}{c}\text { Dry Weight average } \\
\left(\mathrm{gm}^{*} \text { plant }^{-1}\right)\end{array}$ & $\begin{array}{c}\text { Shoot Count } \\
\text { average shoots* }^{*} \text { plant }^{-1} \text { ) }\end{array}$ \\
\hline $1(1.22)$ & $0.07 \mathrm{a}$ & $3.71 \quad \mathrm{a}$ \\
\hline $2(4.45)$ & $0.16 \mathrm{~b}$ & $4.71 \mathrm{ab}$ \\
\hline $3(11.56)$ & $0.23 \mathrm{~b}$ & $5.71 \mathrm{~b}$ \\
\hline $4(71.52)$ & $0.43 \mathrm{c}$ & $\begin{array}{ll}5.57 & \mathrm{~b}\end{array}$ \\
\hline LSD* at $5 \%$ & 0.07 & 1.53 \\
\hline
\end{tabular}

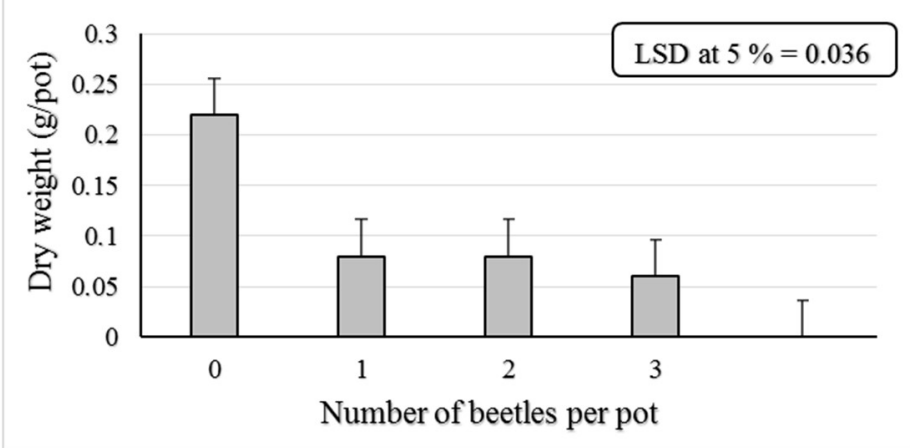

Fig. 1. Effect of the number of beetles on Rumex crispus mean dry weight ( $g$ *plant-1). Results are combined for all 4 seedling growth stages and shown for four different beetle treatments $(0-3$ beetles per plant). 0 beetles is the control treatment. LSD (least significant difference) for all means is shown at $5 \%$ significance.

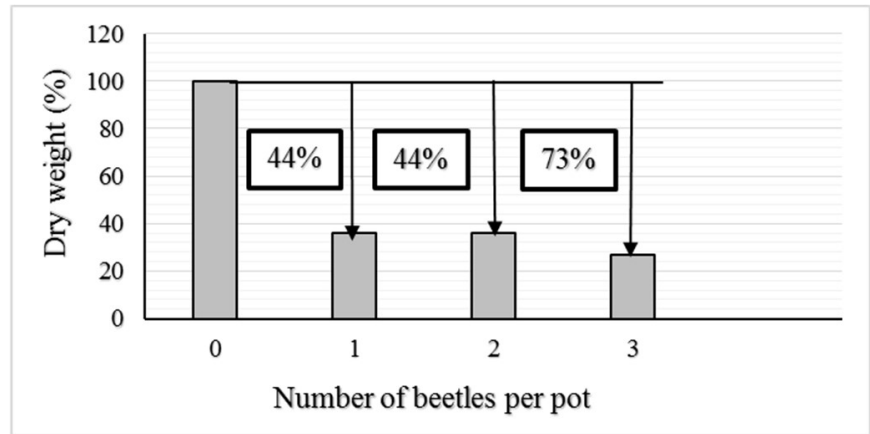

Fig. 2. Percentage (\%) of reduction of average dry weight per plant of Rumex crispus as a result of four numbers of beetles. 


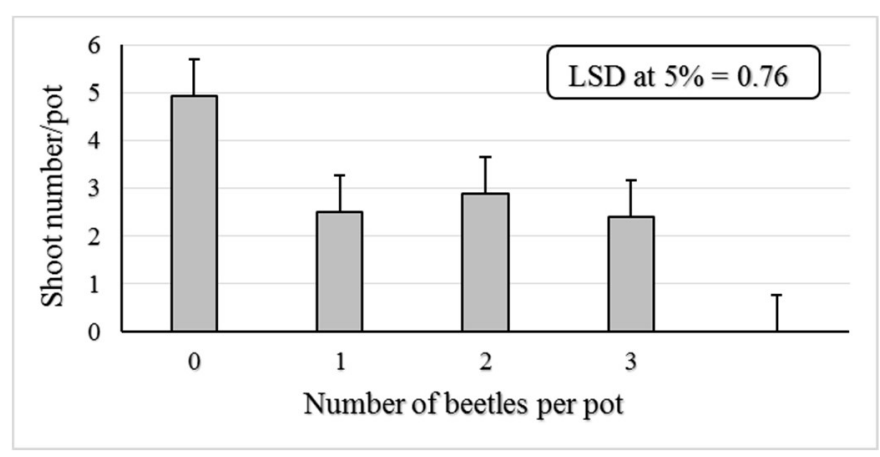

Fig. 3. Effect of the number of beetles on the shoot number of Rumex crispus (shoots per pot). LSD (least significant difference) for all means is shown at $5 \%$ significance.

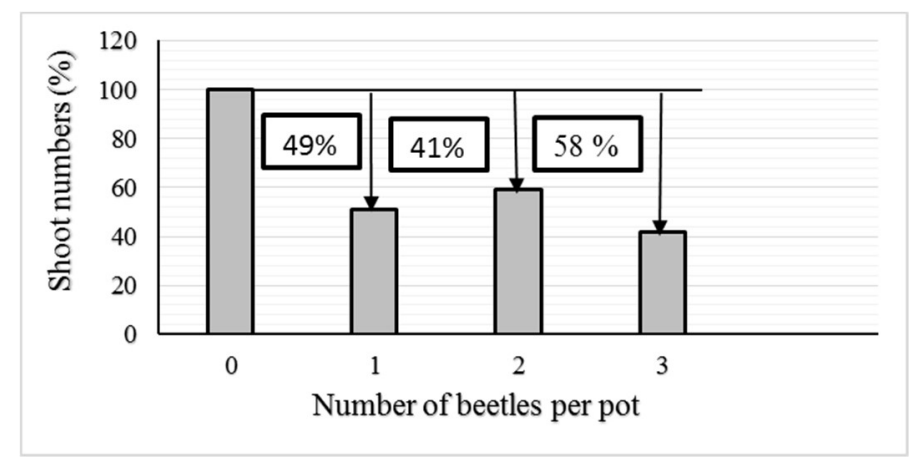

Fig. 4. Percentage (\%) of reduction of average shoot numbers per plant of Rumex crispus as a result of four numbers of beetles.

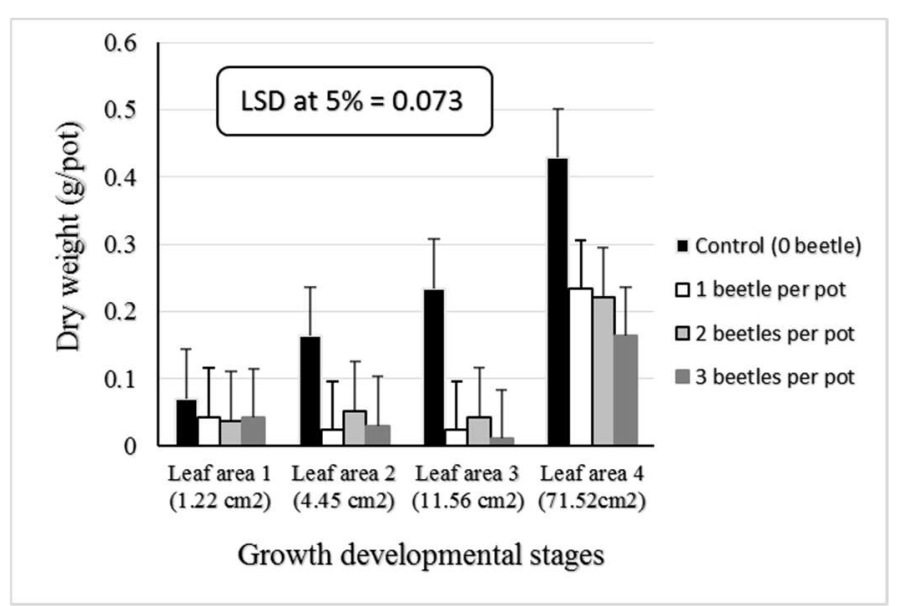

Fig. 5. Effect of different number of beetles on Rumex crispus dry weight (g*plant-1) at 4 seedling growth stages. Results are shown for 4 different beetle treatments (0-3 beetles/plant) and 4 growth stages. LSD (least significant difference) for all means is shown at $5 \%$ significance. 


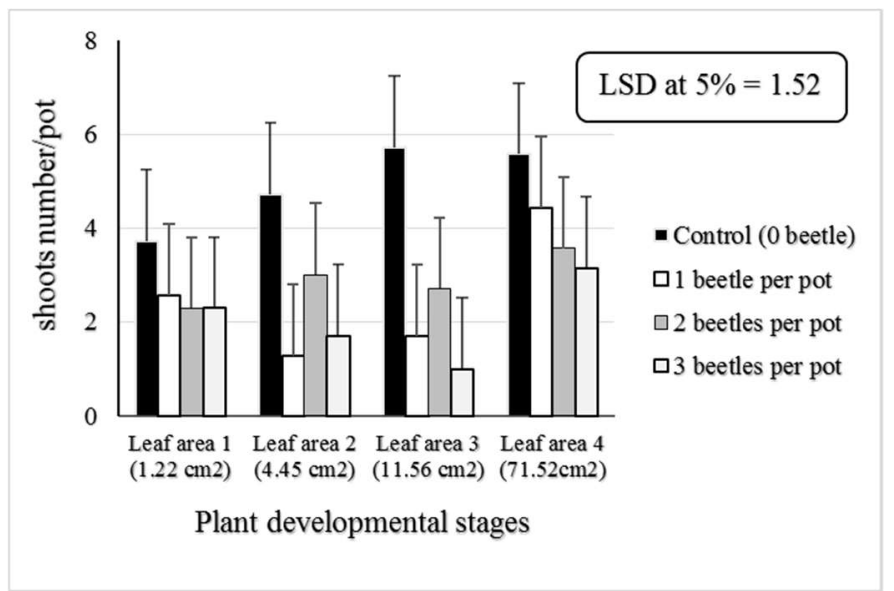

Fig. 6. Effect of different number of beetles on Rumex crispus on shoot numbers per plant of Rumex crispus. Results are shown for 4 different beetle treatments (0-3 beetles/plant) and 4 growth stages. LSD (least significant difference) for all means is shown at $5 \%$ significance.

\subsection{Regeneration of $R$. crispus Seedlings After Beetle Grazing}

Three months after beetle grazing, the $R$. crispus seedlings grazed by beetles at growth stages 1-3 did not regrow, and their death was confirmed (Table 2). The plants at stage 4 (leaf area: $71.52 \mathrm{~cm}^{2}$ ), were able to regrow after any tested level of beetle grazing.

Table 2. Number of re-grown plants of Rumex crispus three months after beetle infestation. The shoot count per plant is shown for each of the four growth stages and four levels of beetle grazing. 0 is the control treatment.

\begin{tabular}{|c|c|c|c|c|c|}
\hline $\begin{array}{c}\text { Growth stage } \\
\text { (average leaf } \\
\text { area/plant, } \\
\mathrm{cm}^{2} \text { ) } \downarrow\end{array}$ & $\begin{array}{c}\text { Beetle } \\
\text { Level }\end{array} \rightarrow$ & $\begin{array}{c}\mathbf{0} \\
\text { (control) }\end{array}$ & 1 & 2 & 3 \\
\hline $1(1.22)$ & & 2 & 0 & 0 & 0 \\
\hline $2(4.45)$ & & 3 & 0 & 0 & 0 \\
\hline $3(11.56)$ & & 3 & 0 & 0 & 0 \\
\hline $4(71.52)$ & & 3 & 2 & 2 & 1 \\
\hline
\end{tabular}

\subsection{Correlation between Growth Measurements} (Dry Weight and Number of Shoots) of R. crispus

Statistical analysis showed correlation (Pearson's $\mathrm{r}=0.77, \mathrm{P}=\leq 0.001$ ), between the dry weight $\left(\mathrm{g}^{*}\right.$ plant $\left.^{-1}\right)$ of $R$. crispus seedlings and the number of shoots (shoots per plant) at all four growth stages, confirming that as dry weight decreases, so does the number of shoots. This suggests that beetles grazing on leaves and stems has relatively similar effect and also similar preference.

\section{Discussion}

The use of biological agents to control the invasive and economically very important weed, Rumex crispus, has been investigated since at least the 1970's, however, the present study add to the research to focus on the impacts of the natural dock predator green dock beetle, Gastrophysa viridula, at the seedling stage. Results clearly showed that the dock produces multiple shoots at, or immediately post, seed emergence, and if damaged, grazed shoots are not replaced, since no new ones were produced even after 3 months of recovery from beetle grazing. This confirms that feeding at the seedling stage is likely to contribute to the effective control of this species. Green dock beetle feeding at the youngest dock seedling stage tested, showed a nonsignificant reduction. However, this may attributed to the very limited amount of suitable fodder available in such small plants (total surface area $1.22 \mathrm{~cm}^{2}$ ). Intensity of herbivory is known to depend on the intensity and quality of the dock leaves (Renner, 1970). 
Thus very small seedlings may provide insufficient substance to sustain grazing, or this may affect the beetle's feeding behaviour. Further research is necessary to explore the reasons for this result, given that at all 3 later seedling stages infection by any number of beetles was found to damage the dock as evidenced by a significant reduction in biomass, suggesting it is an effective biocontrol of seedlings, even at low infestation rates, under laboratory conditions.

Infestation by one beetle reduced the average dry weight of $R$. crispus by $63 \%$ and only to $73 \%$ with 3 beetles' infestation. Pearson and Brooks (1996) found equivalent effects, with beetle infestation resulting in $70 \%$ loss of leaf area of mature $R$. obtusifolius. Beetles in low densities (1-3 beetles), as found in the present laboratory investigation caused, approximately, the same reduction percentage in both dry weight and shoot numbers. Those, could potentially have significant control effects, if infestation took place when $R$. crispus is in early growth stage. Mixed results were achieved, particularly in shoot count reduction, when beetle numbers varied from 13 , which may be attributed to various factors, such as, the beetles' feeding habits and their condition during the grazing period, or to competition between beetle individuals or microclimatic conditions under the plastic bags. This confirms that further work are needed, under laboratory and field conditions, to determine the optimal releasing rate, and the effects of the available environmental and ecological conditions on the used herbivory.

The competitive ability of mature $R$. obtusifolius plants has also been shown to be affected notably by the beetle $G$. virdula (Cottam et al., 1986). Furthermore, adult beetles were discovered up to $100 \mathrm{~m}$ from their releasing point (Naito et al., 1979), suggesting that they are having high potential for Rumex spp. control at different growth stages. In the present study, adult beetle males and females were used. It had been reported that late larval stages can graze more rapaciously than adults (Martinkova \& Honek, 2004). The present results indicated sufficient control of dock seedlings at three of the early plant growth stages as $R$. crispus was unable to regenerate until 90 days after the cessation of beetle grazing. But those grazed at the oldest growth stage, some seedlings were later able to regrow. If a longer grazing period could secure sufficient control, may be demonstrated by further work. The rapaciousness of a single beetle was confirmed by its effect on the whole above ground vegetative growth of $R$. crispus, as shown by the correlation (0.77) between the reductions in dry weight and number of shoots. This suggests that, at the early dock growth stages, beetles could potentially kill the seedlings entirely. Hatcher et al. (1994) considered that combining beetle grazing with other control methods at older growth stages might provide better results in suppressing docks.

\section{Conclusion}

Promising results were achieved in this research, particularly the amount of reduction in Rumex vegetative growth at seedling stages by beetle grazing, although the beetles were released in low numbers of beetles. Also, the disability of Rumex small seedlings to regrow. However, this work needs to be repeated on a larger scale and in the field, to observe beetle behaviour end effectiveness under natural conditions.

\section{- Competing interests}

The author declares that he has no competing interests.

\section{- Funding} Arabia.

British Council - Riyadh office - Saudi 
Acknowledgment: The author should thank the British Council - Riyadh office - Saudi Arabia for providing a partial funding to carry out this research work at the University of Reading-UK. I would like also to thank Dr Paul E. Hatcher from School of Biological Sciences, University of Reading for accepting me to enrol in the school as academic visitor, and for his valuable gaudiness during practical part of this research work.

\section{References}

Bach A, (1992). Ergebnisse der flächendeckenden Ampferbekämpfung in etablierten Beständen. In: Erfährungen und Ergebnisse bei der Bekämpfung von Ampfer (Rumex obtusifolius L.) auf mehreren Grünlandstandorten unter Praxisbedingungen (ed. Martin-Luther-Universitat HalleWrittenberg) 1-15.

Belz R G, Reinhardt C F, Foxcroft $\mathbf{L} \mathbf{C}$ and Hurle $\mathbf{K}$ (2007). Residue allelopathy in Parthenium hysterophorus L. -Does parthenin play a leading role? Crop Prot., 26 (3): 237-245.

Cavers P B and Harper J L (1964). Biological flora of British Isles. Rumex obtusifolius L. and Rumex crispus L. Journal of Ecology, 52, 737-766.

Cottam D A, Whittaker, J B and Malloch A J C (1986). The effects of chrysomelid beetle grazing and plant competition on the growth of Rumex obtusifolius. Oecologia, 70: 452-456.

Voigt D, Hosoda N, Schuppert J and Stanislav G (2011). On the laboratory rearing of green dock leaf beetles Gastrophysa viridula (Coleoptera: Chrysomelidae). Insect Science, 18: 379-384.

Dunbabin V (2007). Simulating the role of rooting traits in crop-weed competition. Field Crops Res., 104: 44-51.

Gallery J (1989). Grünlandverunkrautung. Ursachen, Vorbeugung, Bekämpfung. Leopold Stocker Verlag, Graz. Austria.

Gwynne D C and Murray C B (1985). Weed biology and control in agriculture and horticulture. Batsford Academic and Educational, London, UK.

Harley K and Forno I W, (1992). Biological control of weeds. A Hand book for practitioners and students. Inkata Press, Melbourne, Australia.

Hatcher P E, Paul N D, Ayres P G and Whittaker J B (1994). The effect of an insect herbivore and a rust fungus individually, and combined in sequence, on the growth of two Rumex species. New Phytol., 128: 71-78.

Hill T A, (1977). The biology of weeds. The Institute of Biology's Studies in Biology No: 79. Oxford and IBH publishing co. Delhi, Bobay, Calcutta.
Hofmann F (1992). Der stumpfblättrige Ampfer and Möglichkeiten seiner Bekämpfing. In: Erfhrungen und Ergebnisse bei der Bekampfung von Ampfer (Rumex obtusifolius L.) auf mehreren Grünlandstandorten unter Praxisbedingungen (ed. Martin-Luther-Universität HalleWrittenberg), 1-13.

Hongo A (1986) Infestation of Rumex obtusifolius L. and distribution pattern of its individual plants in sown grasslands in Eastern Hokkaido. Weed Research, Japan, 31, 300-305.

Huang H T and Yang P (1987). The ancient cultured citrus ant. BioScience, 37(9): 665-671.

Javaid A, Bajwa R, Rabbani N, and Anjum T (2007). Comparative tolerance of six rice (Oryza sativa L.) genotypes to allelopathy of purple nutsedge (Cyperus rotundus L.) Allelopathy J., 20: 157-166.

Julein M and White G (1997). Biological control of weeds: Theory and practical application. ACIAR Monograph No. 49. Australian Center for International Ag. Research, Canberra, Australia

Khanh T D, Chung I M, Xuan T D and Tawata S (2005). The exploitation of crop allelopathy in sustainable agriculture production. J. Agron. Crop Sci., 191: 172-184.

Martinkova $\mathbf{Z}$ and Honek A (2004). Gastrophysa viridula (Coleoptera: Chrysomelidae) and biocontrol of Rumex - a review. Plant Soil and Environment, 50: pp.1-9.

Naito A, Miyazaki M and Kanda K (1979). Studies on the Biological Control of Rumex obtusifolius L., a Grassland weed, by Gastrophysa atrocyanea Mots. (Coleoptera: Chrysomelidae) II. Dispersal of Overwintered Adult Insects. Applied Entomology and Zoology, 14: 51-55.

Oudejan J H, (1994). Agro pesticides, properties and functions in integrated crop protection. United Nations, Economic and Social commission for Asian and Pacific United nations Bangkok: 264-290.

Pearson M and Brooks G L (1996). The effect of elevated $\mathrm{CO} 2$ and grazing by Gastrophysa viridula on the physiology and regrowth of Rumex obtusifolius. New Phytol., 133: 605-616.

Pino J, Haggar R J, Sans F X, Masalles, R M, Hamilton R N S and Sackville Hamilton R N (1995). Clonal growth and fragment regeneration of Rumex obtusifolius L. Weed Research, 35: 141-148.

Pye A (2008). Ecological studies of Rumex crispus L; Propagation, Competition and Demography. Doctoral Thesis. Swedish University of Agricultural Sciences.

Renner K, (1970). Beziehungen zwischen Nahrungsmenge, Körpergewicht und Entwicklungsalter bei Gastroidea viridula Deg. (Col. Chrysomelidae). Anz. Schädl.-Kde Pfl.-Schutz, 43: 119-122.

Salt D T and Whittaker, J B (1998) Insects on dock plants. The Richmond Publishing Co. Ltd. England.

Sher H and Alyemeny M N (2011). Ecological investigation of weed flora in arable and non-arable lands of Al-karj, 
Saudi Arabia. African Journal of Agricultural Research, 6 : 901-906.

Singh H P, Batish D R, Pandher, J K and Kohli, R K (2005). Phytotoxic effects of Parthenium hysterophorus residues on three Brassica species. Weed Biol. Managm., 5: 105-109.

Strokey J (2006). A functional group approach to the management of UK arable weeds to support biological diversity. Weed Res., 46: 513-522.
Williams P A and West C J (2000). Environmental weeds in Australia and New Zealand: issues and approaches to management. Austral. Ecol., 25: 425-444.

Zaller J G (2004b). Ecology and non-chemical control of Rumex crispus and R. obtusifolius (Polygonaceae): a review. Weed research, 44: 414-432.

Zhao D L, Atlin G N, Bastiaans L and Spiertz, J H J (2006). Developing selection protocols for weed competitiveness in aerobic rice. Field Crops Res., 97: 272285. 
المكافحة الحيوية لأعشاب الحميض في مرحلة البادر ات باستخدام حشرة الحميض

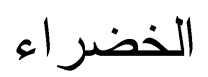

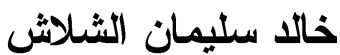

\author{
كلبة العلوم، جامعة شقراء، المملكة العربية السعودية \\ ghassanedrees983@gmail.com
}

المستخلص. في أربع تجارب في البيوت الزجاجية، تمت براسة فعالية استخدام حشرة الحميض الحبل الخضراء وتحديد الأعداد المناسبة منها في المكافحة الحيوية لأعشاب الحميض في في مرحلة التهاته

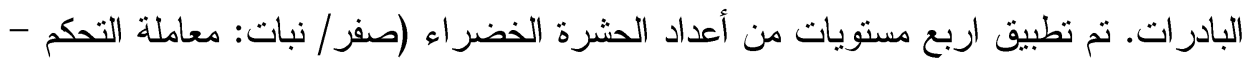

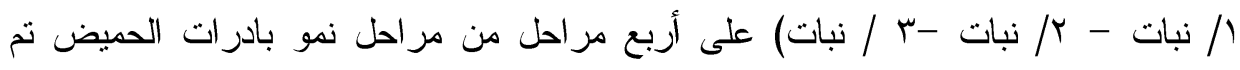

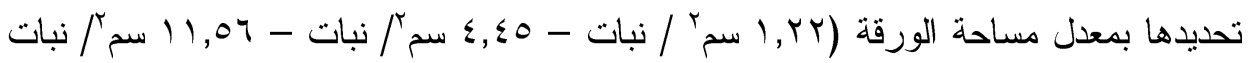
-

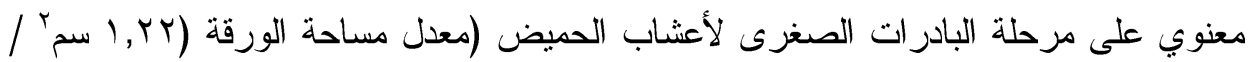

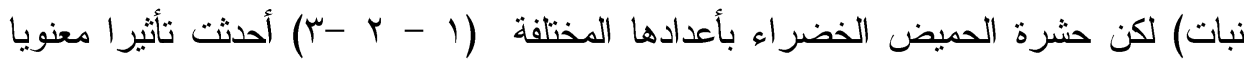

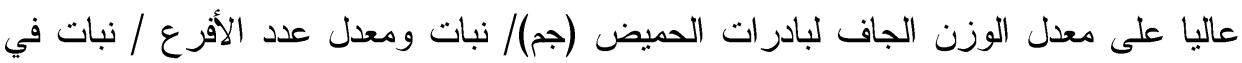

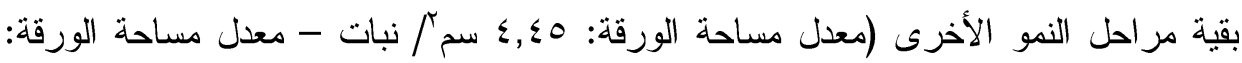

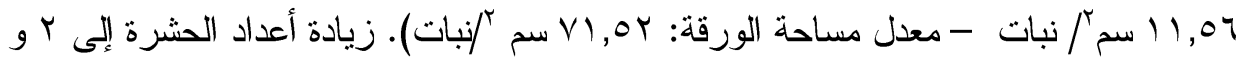

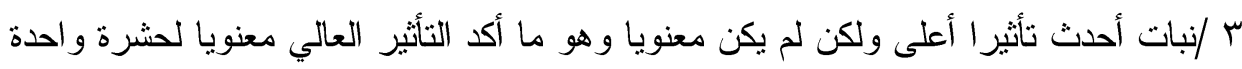
فقط على نمو بادرات الحميض في مراحل النمو المذكورة. بعد ثلاثة أثثر لم تنستطيع بادرات

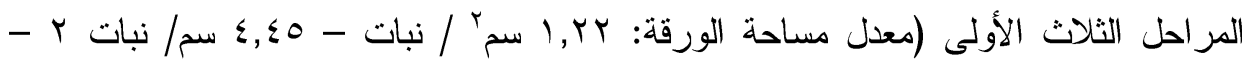

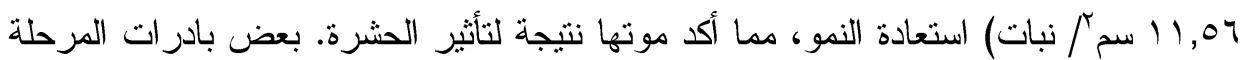

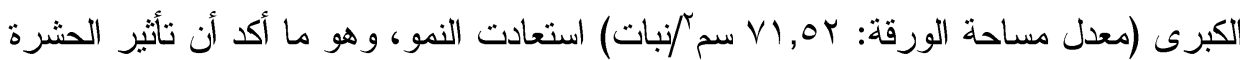
الأقوى على نمو بادرات الحميض كان في المراحل الثلاث الصغرى. أوضح التحليل الإحصائي

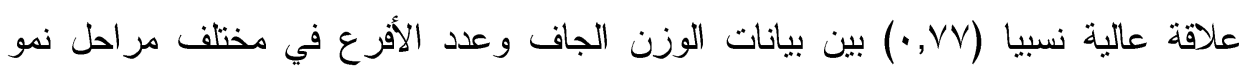

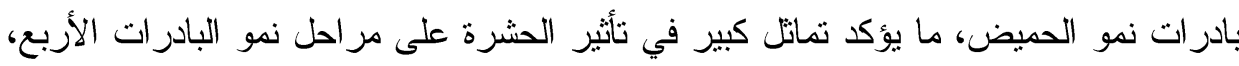

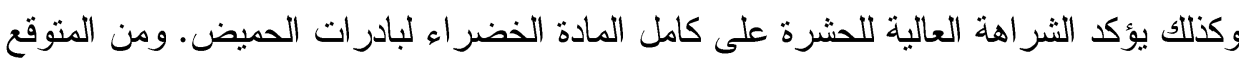
أن يكون تأثير الحشرة الخضراء على بادرات الحميض الكبرى أكبر بمشاركة طرق مكافحة 
